\title{
AEROMAGNETIC MAP OF PART OF THE HYANNIS QUADRANGLE AND VICINITY, BARNSTABLE COUNTY, MASSACHUSETTS
}

\author{
GEOPHYSICAL INVESTIGATIONS \\ MAP GP-805
}

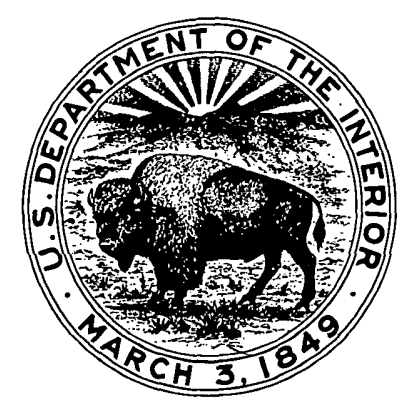

